\title{
Geochemistry of advanced argillic altered rocks in the area of Breznik, Western Srednogorie Unit (Bulgaria)
}

\author{
Atanas Hikov ${ }^{l}$, Nadezhda Velinova ${ }^{I}$, Catherine Lerouge ${ }^{2}$, Angel Kunov ${ }^{l}$ \\ ${ }^{1}$ Geological Institute, Bulgarian Academy of Sciences, 1113 Sofia, Bulgaria; e-mails: ahikov@geology.bas.bg; \\ nvel@geology.bas.bg; angelkunov@abv.bg \\ ${ }^{2}$ BRGM, BP 6009, 45060 Orléans cédex 2, France; e-mail: c.lerouge@brgm.fr \\ (Accepted in revised form: July 2017)
}

\begin{abstract}
The distribution and behaviour of major and trace elements in the main zones of hydrothermal alteration (propylite, sericite and advanced argillic) in the area of Breznik Town have been studied, coupled with the chemical composition of alunite group minerals and their isotope geochemistry. The content of $\mathrm{Sr}$ decreases in propylite and especially in sericite rocks, and increases significantly in advanced argillic altered (AAA) rocks, which is connected with the formation of aluminium phosphate-sulphate (APS) minerals. Rubidium has high content in sericitic rocks, whereas the element is almost depleted in AAA rocks. The $\mathrm{Rb} / \mathrm{Sr}$ ratio increases in sericitic rocks and strongly decreases in AAA rocks. Zirconium, Ti, Cr, V, Ga, Hf, $\mathrm{Nb}, \mathrm{Ta}, \mathrm{Th}, \mathrm{U}$ and partially $\mathrm{Sn}$ and Ba have comparatively inert behaviour during alteration. Manganese, $\mathrm{Zn}, \mathrm{Ni}, \mathrm{Co}, \mathrm{Cs}$ and $\mathrm{Y}$ are mobile in different degree, with a trend toward complete extraction in the most altered rocks. Arsenium concentrates in AAA rocks, while Li is concentrated only in kaolinite AAA rocks. LREE are comparatively inert in AAA rocks, while MREE and HREE are very mobile, especially in alunite rocks. Alunite has Na-K composition, with permanent admixtures of $\mathrm{Ca}, \mathrm{Sr}, \mathrm{Ba}$ and LREE. APS minerals themselves are woodhouseite and svanbergite-woodhouseite solid solutions (s.s.). Stable isotopes of alunite are characteristic for magmatic-hydrothermal alunite, whereas $\delta^{34} \mathrm{~S}$ of jarosite is intermediate between $\delta^{34} \mathrm{~S}$ of alunite and sulphides, which confirms its supergene origin. All these features define a high-sulphidation epithermal environment, and a possible porphyry mineralization at deeper part of the system is suggested.
\end{abstract}

Hikov, A., Velinova, N., Lerouge, C., Kunov, A. 2017. Geochemistry of advanced argillic altered rocks in the area of Breznik, Western Srednogorie Unit (Bulgaria). Geologica Balcanica 46 (1), 93-108.

Keywords: geochemistry, trace elements, alunite, APS minerals, advanced argillic alteration, Western Srednogorie Unit.

\section{INTRODUCTION}

The formation of hydrothermally altered rocks is commonly connected with ore deposition, and for that reason they both are considered as integral parts of hydrothermal ore deposits. Advanced argillic alteration (Meyer and Hemley, 1967) and metasomatic rocks of the secondary quartzite formation (Zharikov and Omel'yanenko, 1978), which are genetic analogues in the classification of wall rock alteration and the genetic classification of metasomatites (Kanazirski, 2011), are important criteria for prospecting of highsulphidation epithermal $\mathrm{Au}$ deposits (Hedenquist et al., 2000). More than 30 occurrences of advanced argillic alteration (secondary quartzites) are known in Bulgaria (Velinov et al., 2007). They are concen- trated mainly in the Srednogorie Zone and the Central and Eastern Rhodopes. Some of them associate with porphyry copper and epithermal deposits. Similar link between hydrothermal alteration and epithermal mineralization is seen in the area of Breznik, but the ore potential of the magmatic-hydrothermal system has not been clarified completely. Petrological, mineralogical and metallogenic studies have been carried out, but geochemical features of hydrothermal alterations, especially the distribution and behaviour of trace elements, have been considered less well.

The aim of this study is to show the distribution of chemical elements in the alteration zones and to explain their behaviour during advanced argillic alteration and related metasomatic alterations, with special emphasis on trace elements. The study of the distribu- 
tion of trace elements in the different alteration types will contribute to complete understanding of advanced argillic alteration, as well as to geochemical discrimination between ore forming and accompanying processes. Finally, the aim is to find geochemical criteria for distinguishing productive from unproductive alteration zones, as well as to find vectors to the mineralizing centre and potentially new ore mineralization.

\section{GEOLOGICAL SETTING}

The hydrothermal alteration zone is located in Bardoto area south of Breznik Town. The area belongs to the western part of the Srednogorie Zone (Fig. 1), which is a part of a regional Late Cretaceous islandarc (Boccaletti et al., 1974). The Srednogorie Zone is also considered a part of a regional metallogenic belt with copper specialization (Vassileff and StanishevaVassileva, 1981) or of the Apuseni-Banat-Timok-
Srednogorie (ABTS) magmatic and metallogenic belt (Popov et al., 2002). The Western Srednogorie Unit is well differentiated tectonic unit known also as "Viskyar-Vitosha synclinorium" (Gočev et al., 1970), "Sofia complex trough" (Bončev, 1971) or "Sofia synclinorium" (Vrablyanski, 1971). Upper Cretaceous (Turonian-Maastrichtian) sedimentary, volcano-sedimentary and volcanic rocks predominate. The age of the magmatic activity is Coniacian-Campanian (Dimitrova et al., 1981).

The alteration zone is formed in the central part of the Breznik palaeovolcano (Bajraktarov and $\mathrm{Mu}-$ tafchiev, 1981), Breznik group volcanos (Nachev et al., 1981) or Breznik magmatic centre (Panayotov et al., 1982), which is a part of the Krasava anticline and the upper volcano-sedimentary unit (Campanian) in the Western Srednogorie Unit (Bajraktarov, 1989; Zagorchev et al., 1995; Dabovski et al., 2009). According to Marinova et al. (2010), these rocks belong to the Pyroclastic formation and intersect trachybasalts

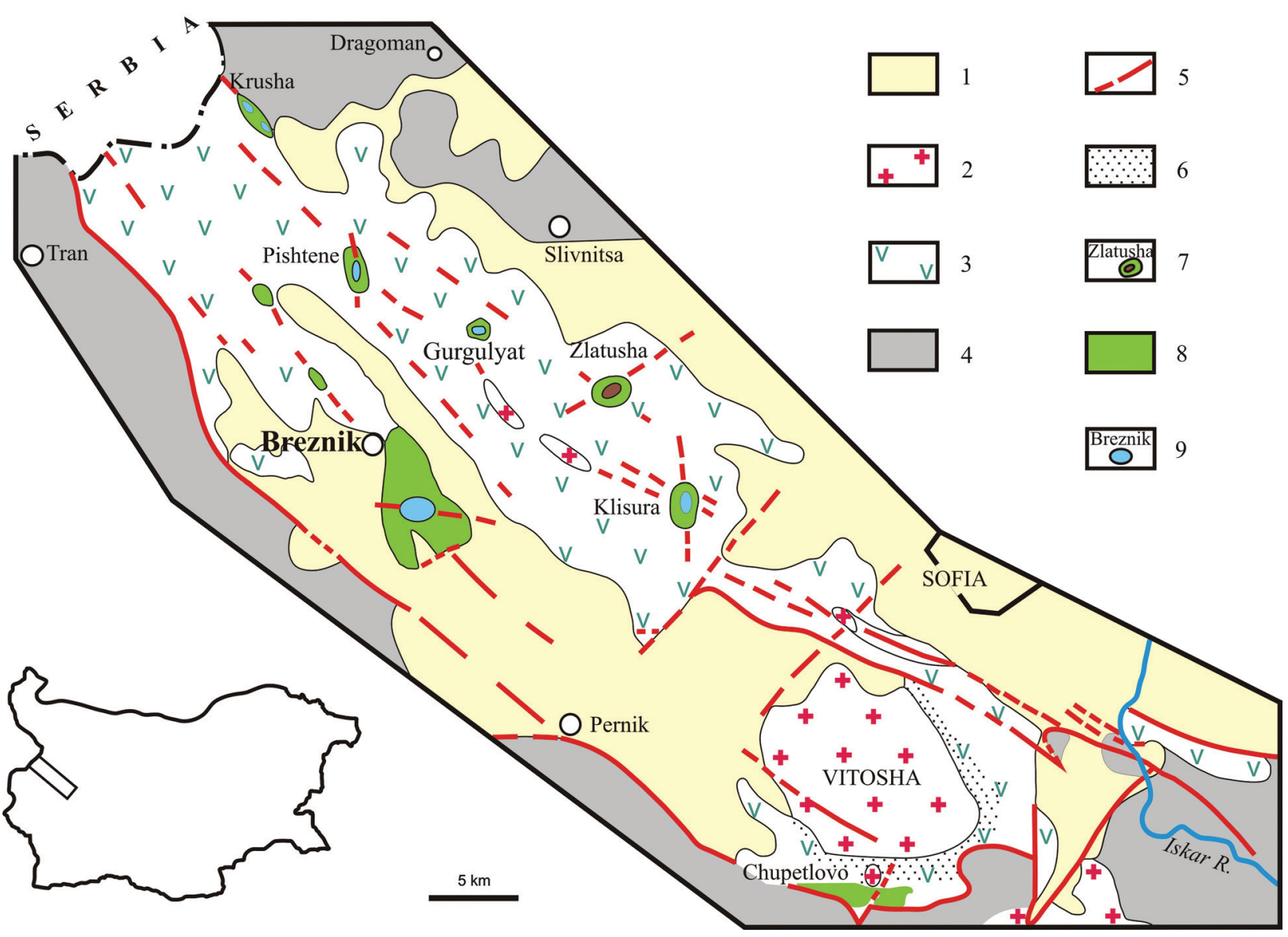

Fig. 1. Geological sketch map of the Western Srednogorie Unit with the occurrences of the altered rocks (modified from Velinov et al., 2007): 1 - "Tertiary"; 2 - Upper Cretaceous intrusive complex; 3 - Upper Cretaceous effusive complex; 4 - pre-Turonian formations; 5 - faults; occurrences of altered rocks: 6 - contact hydrothermally altered rock (uralitizied) andesite lava-breccias, 7 - quartz-sericite-adularia, quartz-adularia and propylite rocks, 8 - propylites, argillisites and quartz-sericite rocks, 9 - secondary quartzites (advanced argillic rocks). 
and shoshonites from the "Babski Volcanic Complex" of early Campanian age. The host rocks are mainly pyroclastic, rarely lava flows, subvolcanic bodies and dykes. The lava breccias are most abundant, mainly composed of fragments of andesites (Belev, 1967; Dimitrov and Belev, 1970), basaltic andesites and trachybasalts (Velinov, 1967; Bajraktarov, 1989) or alkaline basalts (Marinov and Bajraktarov, 1980). The mineral composition consists of plagioclase, pyroxene \pm olivine, rarely amphibole and volcanic glass groundmass with some primary and secondary minerals.

\section{HYDROTERMAL ALTERATION}

The zone with hydrothermally altered rocks has been mapped by a geological team (see Velinov, 1967). Regional propylites and locally developed alterations in the tectonic faults have been identified for the re- gion. The Breznik zone has been referred to the second type and only quartz-sericite facies has been spatially determined, while the other facies are thought to be encountered jointly. The mineralogical and petrological investigations of Velinov (1967) showed a development of propylites (epidote-chlorite-albite, actinolite-epidote-chlorite, quartz-epidote-sericite and quartz-sericite), as well as alunite secondary quartzites (Fig. 2). The alunite quartzites occupy the innermost parts of the altered zone and form positive geomorphological relief. Two bodies of alunite quartzites (both about $0.5 \mathrm{~km}^{2}$ ) are described. They are composed of quartz, chalcedony, quartzine, alunite, rutile, pyrite, Fe-hydroxides and jarosite. Alunite is fine-grained, with $\mathrm{Na}-\mathrm{K}$ composition, and gets to $30-40 \%$ in the rich sections.

Crummy et al. (2001) outlined zonal development of the quartz-kaolinite-alunite, quartz-sericite and propylite alteration types, as well as a later quartz-

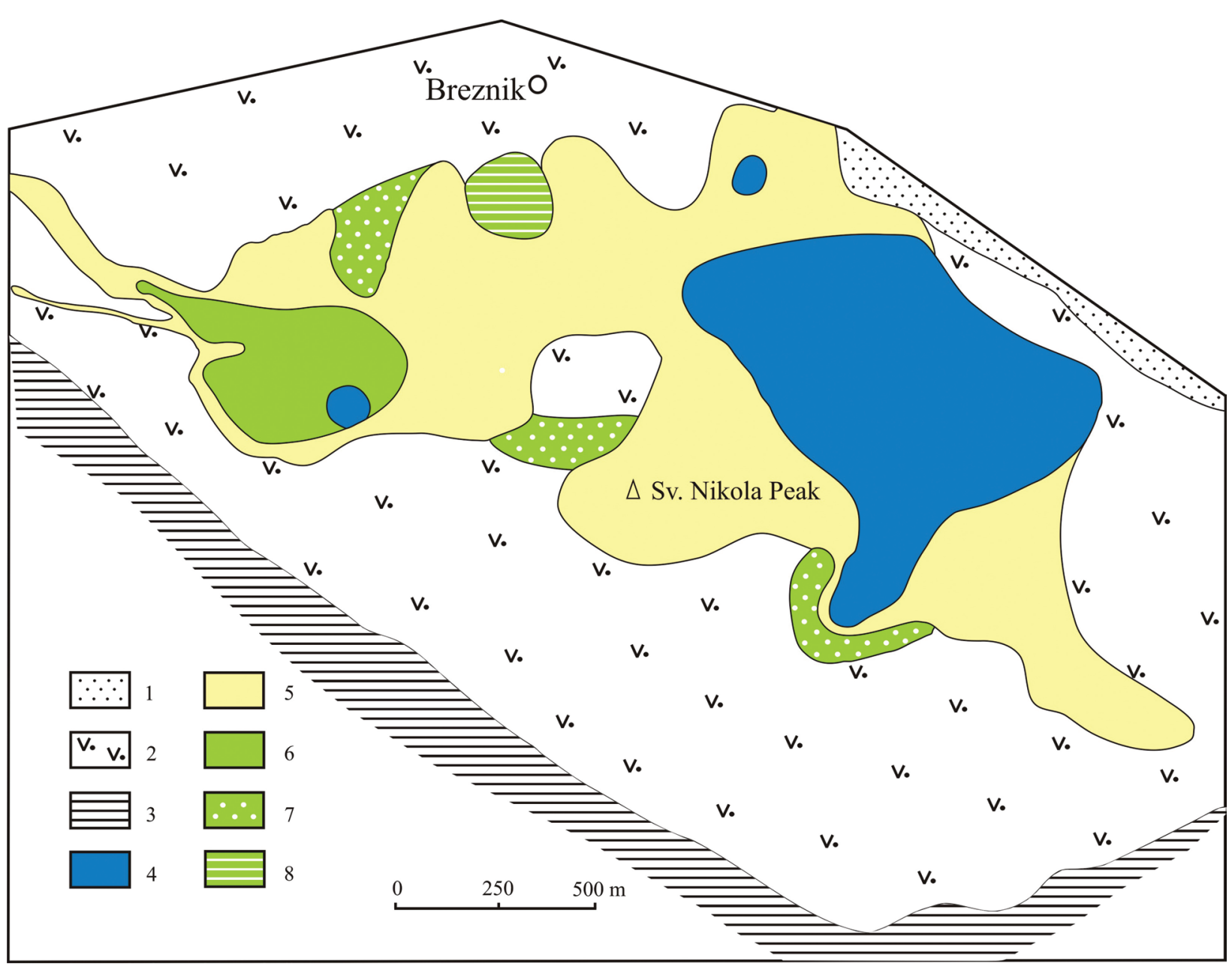

Fig. 2. Schematic geological map of the Breznik area (Velinov, 1967; Velinov et al., 2007): 1 - "Tertiary" sediments; Upper Cretaceous: 2 - agglomerate tuffs with trachybasalt clasts, epidote-chlorite-albite alteration, 3 - tuff-marly complex; altered rocks: 4 - alunite quartzites, 5 - quartz-sericite rocks, 6 - quartz-epidote-sericite rocks, 7 - actinolite-epidote-chlorite rocks, 8 - uraliteepidote-chlorite rocks. 
sericite-carbonate one. The scarce high-sulphidation (enargite-luzonite) mineralization is developed under and into quartz-kaolinite-alunite and quartz-sericite rocks. The rich gold-bearing quartz-sericite-carbonate mineralization is superimposed on the earlier altered rocks. The authors' opinion is that this low-sulphidation type can be classified as "atypical" epithermal gold manifestation with or without sporadic development of adularia. Moritz et al. (2007) discussed juxtaposed high- and low-sulphidation epithermal styles of mineralization, which telescope a porphyry system. Stoykov et al. (2007) described ore mineralization that is characteristic for low-temperature epithermal ore deposits. Lerouge et al. (2007) proved magmatichydrothermal origin of alunite, K-Na zoning of alunite and APS minerals.

Several stages of exploration works were carried out on the Breznik area between 1970 and 2010. Panayotov et al. (1982) concluded that the Bardoto ore occurrence is perspective for porphyry copper and base metal mineralizations. Bajraktarov $(1989,1994)$ defined the Breznik prospective zone with ore occurrences Bardoto (pyrite subformation) and Gorski Dom (pyrolusite-psilomelane-hematite formation). He noted that the zone has potential for prospecting for $\mathrm{Au}$-alunite and Fe-Mn mineralizations, as well as for alunite raw material. As a result of successive exploration work by the company "Trace Resources Ltd", in 2011 the Bardoto occurrence was declared as Milin Kamak ore deposit. At the base case cut-off grade of $2 \mathrm{~g} / \mathrm{t}$ gold, the inferred resource is 2,439,000 tonnes grading $5.91 \mathrm{~g} / \mathrm{t} \mathrm{Au}$ and $26.78 \mathrm{~g} / \mathrm{t} \mathrm{Ag}$ (Carter, 2011). Sabeva (2015) defined the Milin Kamak ore deposit as $\mathrm{Au}-\mathrm{Ag}$ intermediate sulphidation type epithermal deposit with local manifestation of high-sulphidation type. She also described limited development of intermediate argillic and transitional propylite-sericite alteration types.

\section{ANALYTICAL METHODS}

Representative samples from the main hydrothermal alteration types were collected to characterize the geochemistry of altered rocks from the Breznik area. Detailed study of each sample was carried out to define precisely the alteration type and its place in the altera- tion zoning. Mineral composition of altered rocks was examined in thin-sections, supported by X-ray diffraction (XRD) and differential-thermal analyses (DTA) at the Geological Institute of BAS, Sofia. Alunite and aluminium-phosphate-sulphate (APS) minerals were analysed by an electron microprobe Camebax SX50 in BRGM (Orléans, France). The analyses were made by EDS system with acceleration voltage $15-20 \mathrm{keV}$ and current beam 2-6 nA. Raman spectrometry was used to characterize alunite and APS minerals. The spectra were performed, using an XY800 DILOR equipped with an Olympus microscope (objx80ULWD), an exciting radiation of $514.5 \mathrm{~nm}$ of ionized argon laser $(50 \mathrm{~mW})$ in BRGM (Orléans, France).

The whole rocks' chemical composition was studied with X-ray fluorescent (XRF) analysis for the major elements; ICP-EAS for $\mathrm{Cr}, \mathrm{V}, \mathrm{Cu}, \mathrm{Zn}, \mathrm{Ni}, \mathrm{Co}$, $\mathrm{Ag}$ and $\mathrm{Ga}$; atomic absorption (AA) analysis for $\mathrm{Li}$; and $\mathrm{LA}-\mathrm{ICP}-\mathrm{MS}$ for $\mathrm{Ba}, \mathrm{Zr}, \mathrm{Sr}, \mathrm{Rb}, \mathrm{Pb}, \mathrm{Sn}, \mathrm{Y}, \mathrm{Hf}$, $\mathrm{Ta}, \mathrm{Nb}, \mathrm{Cs}, \mathrm{U}, \mathrm{Th}, \mathrm{As}, \mathrm{Sb}, \mathrm{Te}, \mathrm{Bi}, \mathrm{REE}$ and $\mathrm{Au}$ at the Geological Institute (BAS, Sofia). One sample of alunite rock was analysed by ICP-MS at Acme Labs Ltd (Vancouver, Canada). Isotope data on $\mathrm{Sr}, \mathrm{S}, \mathrm{O}$ and $\mathrm{H}$ were obtained at the Laboratory of Stable Isotopes and Low Radioactivity of the BRGM (Orléans, France). Oxygen, sulphur and hydrogen isotopes of alunite were analysed, using the analytical methods described by Lerouge et al. (2006).

\section{GEOCHEMISTRY}

\section{Geochemistry of alteration zones}

The main hydrothermal alteration types were sampled to clarify the geochemical features of advanced argillic altered rocks. The distribution and behaviour of chemical elements with the increasing alteration degree from unaltered volcanic rocks to propylite, sericite (Fig. $3 a-c$ ) and advanced argillic altered rocks were studied. Only the most widespread and characteristic epidote-chlorite-albite \pm carbonate propylitic alteration type was examined. Advanced argillic altered rocks (secondary quartzites) consist of three different types. Besides the known alunite and alunite-kaolinite alterations (Fig. $3 d, e$ ), the pyrophyllite-bearing advanced argillic rocks were distinguished during this

\footnotetext{
Fig. 3. Microphotographs of fresh and altered rocks from the Breznik area: a) plagioclase (Pl) and pyroxene (Px) porphyries in unaltered trachybasalt (crossed polarizers); $b$ ) albite $(\mathrm{Ab})$, chlorite $(\mathrm{Chl})$, epidote $(\mathrm{Ep})$ and carbonate $(\mathrm{Ct})$ in propylite rock (planepolarized light); $c$ ) sericite (Ser), quartz (Qtz) and pyrite (Py) in sericite rock (plane-polarized light); $d$ ) quartz (Qtz) and alunite (Alu) in alunite advanced argillic rock (crossed polarizers); e) quartz (Qtz) and kaolinite (Kaol) in kaolinite advanced argillic rock (crossed polarizers); $f$ ) quartz (Qtz) and pyrophyllite (Pyr) in pyrophyllite advanced argillic rock (crossed polarizers); $g$ ) core of APS mineral in alunite (Alu) among quartz (Qtz) (plane-polarized light); $h$ ) APS minerals, rutile (Rut) and kaolinite (Kaol) in kaolinite advanced argillic rock (plane-polarized light).
} 

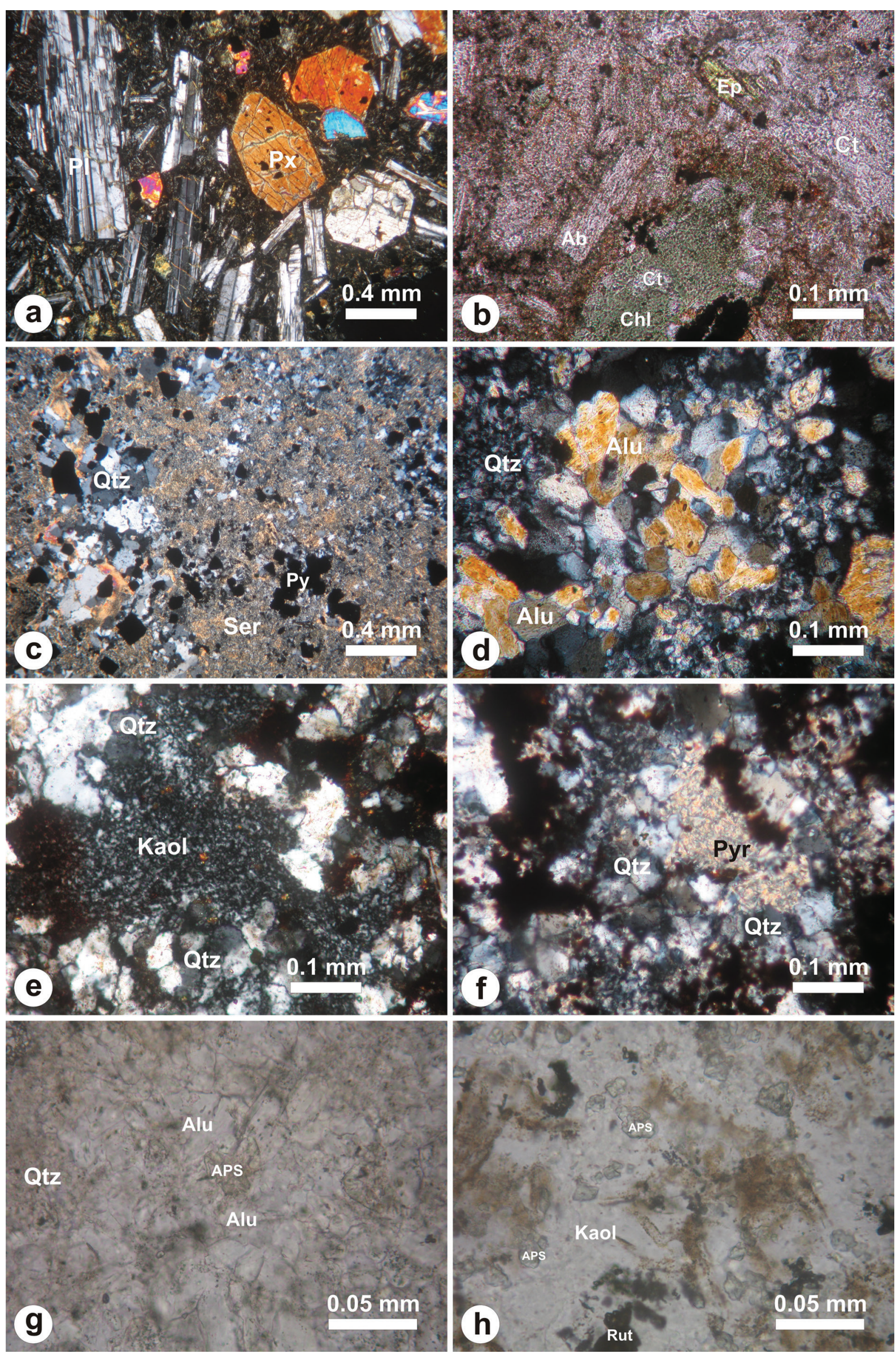
study. These consist of mainly quartz, pyrophyllite and Fe-oxyhydroxides (Fig. 3f). All advanced argillic altered types contain aluminium-phosphate-sulphate (APS) minerals (woodhouseite and svanbergitewoodhouseite s.s.). They usually occur as microscopic pseudocubic crystals, which can form cores of alunite crystals (Figs $3 g, h, 4$ ). The composition of mineral water, which springs from the alteration zone, was also analysed.

Statistically unrepresentative "mean value" is used in Table 1 and Fig. 5 to show the main trends of behaviour of chemical elements in advanced argillic rocks. When a single element behaved differently in different advanced argillic alteration types, conclusions were made separately for each alteration type.

New geochemical data confirm the conclusions of Velinov (1967) for gradual extraction of most major elements with increase of the alteration degree (Table 1; Fig. $5 a$ ), and even $\mathrm{SiO}_{2}$ and $\mathrm{Al}_{2} \mathrm{O}_{3}$ are partly mobile in advanced argillic altered rocks. The contents of $\mathrm{K}_{2} \mathrm{O}$ in alunite rocks are close to these in unaltered volcanic rocks; they are considerably higher in sericitic rocks $(4.10 \%)$, while the element is fully extracted from kaolinite and pyrophyllite altered rocks. $\mathrm{Na}_{2} \mathrm{O}$ concentrates in propylite rocks, which is connected with the formation of albite, and decreases in sericite and in advanced argillic rocks, where it can be included only in alunite, APS minerals and probably sericite. $\mathrm{CaO}$ and $\mathrm{MgO}$ weakly decrease in propylite rocks because of the presence of epidote, carbonate and chlorite and are almost depleted in sericite and advanced argillic rocks.

Concentration of $\mathrm{Sr}(955 \mathrm{ppm}$ in unaltered volcanic rocks) decreases in propylite $(492 \mathrm{ppm})$ and especially in sericite rocks (31 ppm) and increases significantly in advanced argillic altered rocks (mean
2010 ppm) (Table 1; Fig. 5b). Strontium values are high in all types of advanced argillic alteration, being highest in the kaolinite type (3340 ppm). This high-Sr content is connected with the formation of APS minerals with svanbergite-woodhouseite composition, as well as admixture in alunite whose compositions will be discussed below.

Rubidium content increases in K-bearing sericite rocks (Fig. 5b), while the element is almost depleted in advanced argillic altered rocks, despite the significant $\mathrm{K}_{2} \mathrm{O}$ concentration in alunite rocks. The $\mathrm{Rb} / \mathrm{Sr}$ ratio increases from 0.05 in unaltered rocks to 0.17 in propylite and to 5.56 in sericite rocks and strongly decreases to 0.002 in advanced argillic altered rocks (Fig. $5 d$ ).

The elements Ni, Co and Y show different degrees of mobility, with a trend to complete extraction in the most altered rocks, while other elements concentrate in a single zone (e.g., $\mathrm{Mn}$ and $\mathrm{Zn}$ in propylite and $\mathrm{Cs}$ in sericite) and are depleted in the rest of the zones (Fig. 5c, g). Zirconium, Ti, V, Ga, Hf, Nb, Th, U and, to a lesser extent, $\mathrm{Cr}$, $\mathrm{Ta}, \mathrm{Sn}$ and $\mathrm{Ba}$ have comparatively inert behaviour during hydrothermal alteration (Fig. $5 e, f$ ). Arsenium concentrates several times in advanced argillic altered rocks, while Li increases only in kaolinite-containing advanced argillic rocks (Fig. 5h). Antimony, Te and Bi tend to concentrate in sericite and advanced argillic rocks, with the highest contents in kaolinite rocks.

The concentrations of $\mathrm{Cu}$ and $\mathrm{Pb}$ (Fig. $5 g$ ) are higher in unaltered volcanic rocks and especially in single altered samples, possibly as a result of the ore mineralization. For that reason, conclusions about their behaviour during hydrothermal alteration cannot be made. Silver has permanent comparatively high contents in all samples (Fig. 5f), while Au is detected
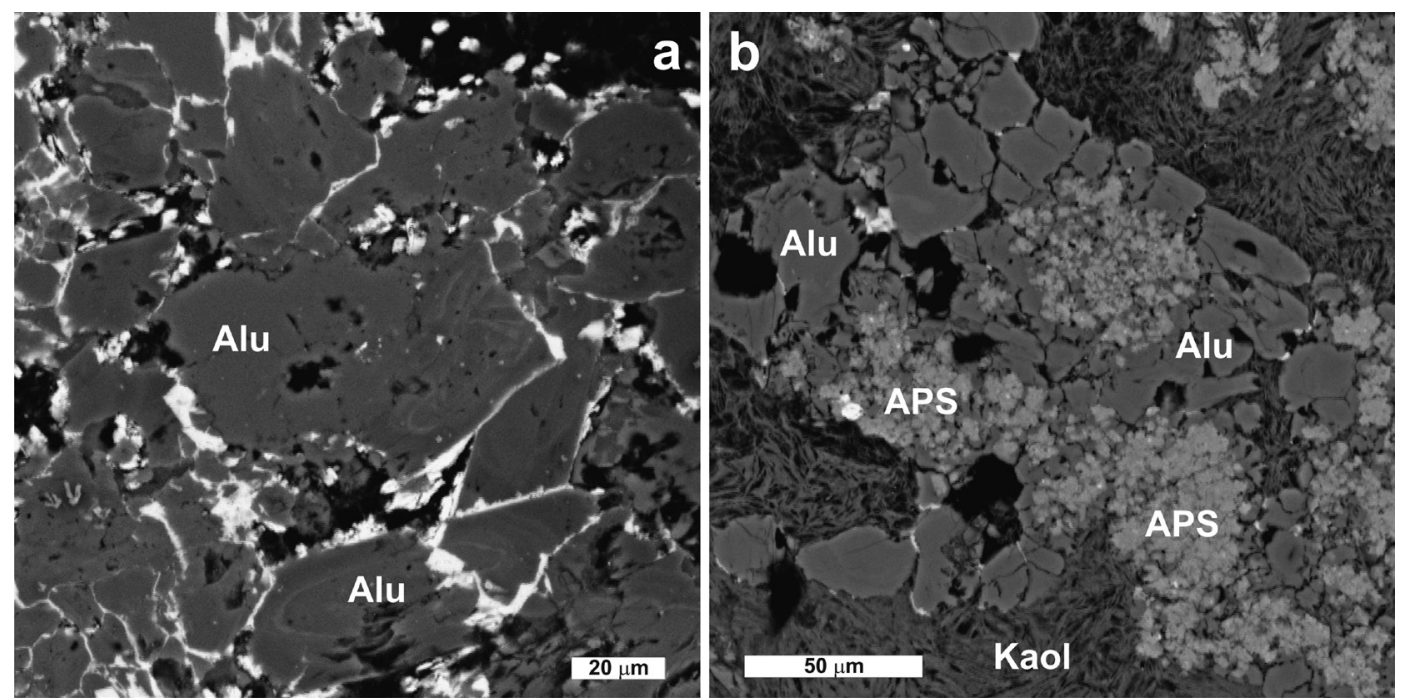

Fig. 4. BSE images of alunite and APS minerals from the Breznik area: $a$ ) alunite with K-Na chemical zoning; $b$ ) heapings of microscopic pseudocubic APS crystals among alunite and kaolinite. 
Table 1

Chemical composition of hydrothermally altered rocks from the area of Breznik

\begin{tabular}{|c|c|c|c|c|c|c|c|c|}
\hline Sample & 646 & 647 & 648 & 643 & 644 & 645 & $645 \mathrm{~A}$ & Mean \\
\hline Rocks & 1 & 2 & 3 & $4(\mathrm{Kaol})$ & 4(Pyr) & $4(\mathrm{Al})$ & $4(\mathrm{Al})$ & 4 \\
\hline $\mathrm{SiO}_{2}, \%$ & 51.02 & 47.95 & 69.53 & 62.15 & 64.39 & 58.09 & 54.25 & \\
\hline $\mathrm{TiO}_{2}$ & 0.87 & 0.70 & 0.99 & 1.33 & 1.15 & 1.03 & 1.11 & 1.16 \\
\hline $\mathrm{Al}_{2} \mathrm{O}_{3}$ & 14.62 & 14.19 & 14.65 & 20.04 & 10.52 & 15.36 & 13.04 & \\
\hline $\mathrm{Fe}_{2} \mathrm{O}_{3}{ }^{\mathrm{t}}$ & 10.55 & 6.84 & 1.52 & 6.23 & 15.52 & 1.94 & 9.47 & \\
\hline $\mathrm{MnO}$ & 0.14 & 0.28 & 0.03 & 0.007 & 0.011 & 0.002 & 0.003 & 0.006 \\
\hline $\mathrm{MgO}$ & 5.49 & 2.65 & 0.1 & 0.06 & 0.06 & 0.04 & 0.08 & 0.06 \\
\hline $\mathrm{CaO}$ & 8.72 & 7.18 & 0.3 & 0.42 & 0.48 & 0.34 & 0.73 & 0.49 \\
\hline $\mathrm{Na}_{2} \mathrm{O}$ & 2.97 & 4.85 & 0.65 & 0.58 & 0.69 & 0.55 & 0.35 & 0.54 \\
\hline $\mathrm{K}_{2} \mathrm{O}$ & 2.53 & 2.98 & 4.1 & 0.16 & 0.15 & 2.37 & 2.30 & 1.25 \\
\hline $\mathrm{P}_{2} \mathrm{O}_{5}$ & 0.49 & 0.39 & 0.11 & 0.53 & 0.66 & 0.41 & 0.53 & 0.53 \\
\hline LOI & 2.64 & 12.27 & 7.7 & 8.6 & 7.01 & 20.33 & 18.18 & \\
\hline Sum & 100.04 & 100.28 & 99.68 & 100.04 & 100.57 & 100.42 & 100.04 & \\
\hline $\mathrm{Ba}, \mathrm{ppm}$ & 498.85 & 532.01 & 223.09 & 196.13 & 200.08 & 3266.12 & 434.6 & 1024.23 \\
\hline $\mathrm{Zr}$ & 123.27 & 120.55 & 110.20 & 135.12 & 109.74 & 110.91 & 94.60 & 112.59 \\
\hline $\mathrm{Sr}$ & 954.91 & 491.74 & 30.94 & 3339.86 & 1337.74 & 1838.91 & 1526 & 2010.63 \\
\hline $\mathrm{Rb}$ & 48.10 & 85.16 & 172.16 & 2.58 & 2.57 & 5.66 & 8.40 & 4.80 \\
\hline $\mathrm{Cr}$ & 70.80 & 7.70 & 24.40 & 21.40 & 45.30 & 83.70 & 62.00 & 53.10 \\
\hline V & 208.50 & 153.60 & 214.10 & 244.60 & 308.40 & 114.50 & 201.00 & 217.13 \\
\hline $\mathrm{Cu}$ & 119.40 & 33.60 & 12.40 & 476.60 & 154.40 & 36.20 & 51.19 & 179.60 \\
\hline $\mathrm{Zn}$ & 113.00 & 171.30 & 42.50 & 49.30 & 23.70 & 12.70 & 9.10 & 23.70 \\
\hline $\mathrm{Pb}$ & 16.80 & 19.87 & 449.57 & 301.24 & 0.13 & 302.26 & 413.40 & 254.26 \\
\hline $\mathrm{Ni}$ & 35.00 & 8.60 & 2.70 & 6.90 & 3.50 & 2.90 & 1.70 & 3.75 \\
\hline $\mathrm{Co}$ & 29.80 & 16.50 & 7.80 & 9.40 & 9.00 & 6.80 & 0.90 & 6.53 \\
\hline $\mathrm{Li}$ & 8.00 & 12.00 & 5.00 & 78.00 & 14.00 & 6.00 & 5.00 & 25.75 \\
\hline $\mathrm{Ag}$ & 4.50 & 2.70 & 3.80 & 6.90 & 2.30 & 3.30 & 0.27 & 3.19 \\
\hline $\mathrm{Au}$ & $<0.06$ & $<0.06$ & $<0.08$ & 0.27 & 0.08 & $<0.07$ & 0.05 & \\
\hline $\mathrm{Sn}$ & 3.41 & 4.15 & 2.66 & 6.82 & 4.01 & 13.32 & 4.50 & 7.16 \\
\hline $\mathrm{Ga}$ & 21.80 & 19.20 & 19.00 & 33.10 & 22.80 & 13.90 & 12.76 & 20.64 \\
\hline Y & 23.99 & 23.72 & 8.11 & 12.42 & 8.76 & 4.97 & 3.40 & 7.39 \\
\hline Hf & 3.49 & 3.04 & 2.79 & 3.34 & 2.74 & 2.82 & 1.49 & 2.60 \\
\hline $\mathrm{Ta}$ & 1.81 & 1.13 & 6.34 & 5.34 & 5.08 & 2.61 & 0.10 & 3.28 \\
\hline $\mathrm{Nb}$ & 7.72 & 7.95 & 9.23 & 10.21 & 23.78 & 6.85 & 2.00 & 10.71 \\
\hline Cs & 0.99 & 3.45 & 4.56 & 0.12 & 0.14 & 0.18 & 0.05 & 0.12 \\
\hline $\mathrm{U}$ & 2.48 & 1.58 & 2.02 & 3.17 & 2.28 & 1.68 & 1.50 & 2.16 \\
\hline Th & 7.90 & 6.71 & 4.40 & 7.88 & 6.22 & 6.55 & 4.10 & 6.19 \\
\hline As & 6.19 & $<8.00$ & 12.80 & 144.29 & 166.59 & 48.65 & 305.5 & 166.26 \\
\hline $\mathrm{Sb}$ & 0.96 & 2.21 & 6.44 & 12.42 & 5.11 & 2.80 & 3.02 & 5.83 \\
\hline $\mathrm{Te}$ & 2.61 & 3.39 & 4.84 & 6.97 & 6.35 & 5.35 & & 6.22 \\
\hline $\mathrm{Bi}$ & 0.45 & 0.64 & 1.12 & 7.80 & 1.68 & 1.68 & 1.87 & 3.26 \\
\hline $\mathrm{La}$ & 30.99 & 26.04 & 12.87 & 36.71 & 31.22 & 18.26 & 14.60 & 25.20 \\
\hline $\mathrm{Ce}$ & 65.04 & 53.23 & 26.90 & 78.00 & 69.89 & 36.79 & 33.42 & 54.53 \\
\hline $\operatorname{Pr}$ & 8.36 & 6.70 & 3.16 & 9.89 & 8.59 & 4.42 & 5.30 & 7.05 \\
\hline $\mathrm{Nd}$ & 36.10 & 28.80 & 14.29 & 43.42 & 39.03 & 18.97 & 23.00 & 31.10 \\
\hline $\mathrm{Sm}$ & 7.38 & 5.78 & 2.45 & 9.42 & 7.71 & 3.39 & 4.10 & 6.15 \\
\hline $\mathrm{Eu}$ & 2.10 & 1.36 & 0.74 & 3.27 & 1.67 & 1.17 & 1.00 & 1.78 \\
\hline Gd & 6.14 & 5.13 & 2.36 & 6.55 & 5.78 & 1.80 & 2.50 & 4.16 \\
\hline $\mathrm{Tb}$ & 0.90 & 0.75 & 0.24 & 0.55 & 0.56 & 0.14 & 0.20 & 0.36 \\
\hline Dy & 4.80 & 4.38 & 1.47 & 2.39 & 2.47 & 0.87 & 0.90 & 1.66 \\
\hline Но & 0.86 & 0.87 & 0.28 & 0.46 & 0.37 & 0.16 & 0.10 & 0.27 \\
\hline $\mathrm{Er}$ & 2.50 & 2.42 & 0.94 & 1.22 & 0.91 & 0.70 & 0.60 & 0.86 \\
\hline $\mathrm{Tm}$ & 0.28 & 0.33 & 0.13 & 0.22 & 0.16 & 0.14 & 0.05 & 0.14 \\
\hline $\mathrm{Yb}$ & 2.49 & 1.99 & 1.38 & 1.72 & 1.13 & 0.95 & 0.50 & 1.08 \\
\hline $\mathrm{Lu}$ & 0.35 & 0.32 & 0.15 & 0.29 & 0.19 & 0.16 & 0.05 & 0.17 \\
\hline$\sum$ REE & 168.31 & 138.11 & 67.35 & 194.11 & 169.66 & 87.94 & 86.32 & 134.51 \\
\hline $\mathrm{Rb} / \mathrm{Sr}$ & 0.050 & 0.173 & 5.564 & 0.001 & 0.002 & 0.003 & 0.006 & 0.002 \\
\hline
\end{tabular}

Rocks: 1 - unaltered trachybasalt; 2 - propylitic; 3 - sericitic; 4 - advanced argillic: 4(Kaol) - kaolinite, 4(Pyr) - pyrophyllite, $4(\mathrm{Al})$ - alunite. 
only in advanced argillic altered rocks, being highest in kaolinite $(0.27 \mathrm{ppm})$ rocks.

The chondrite-normalized REE pattern of propylite rocks is very similar to the unaltered volcanic rocks, while significant depletion of all REE is seen in sericite rocks (Fig. $6 a$ ). REE patterns of pyrophyllite and kaolinite rocks show fractionation of some MREE and all HREE, while LREE are comparatively inert, with slight
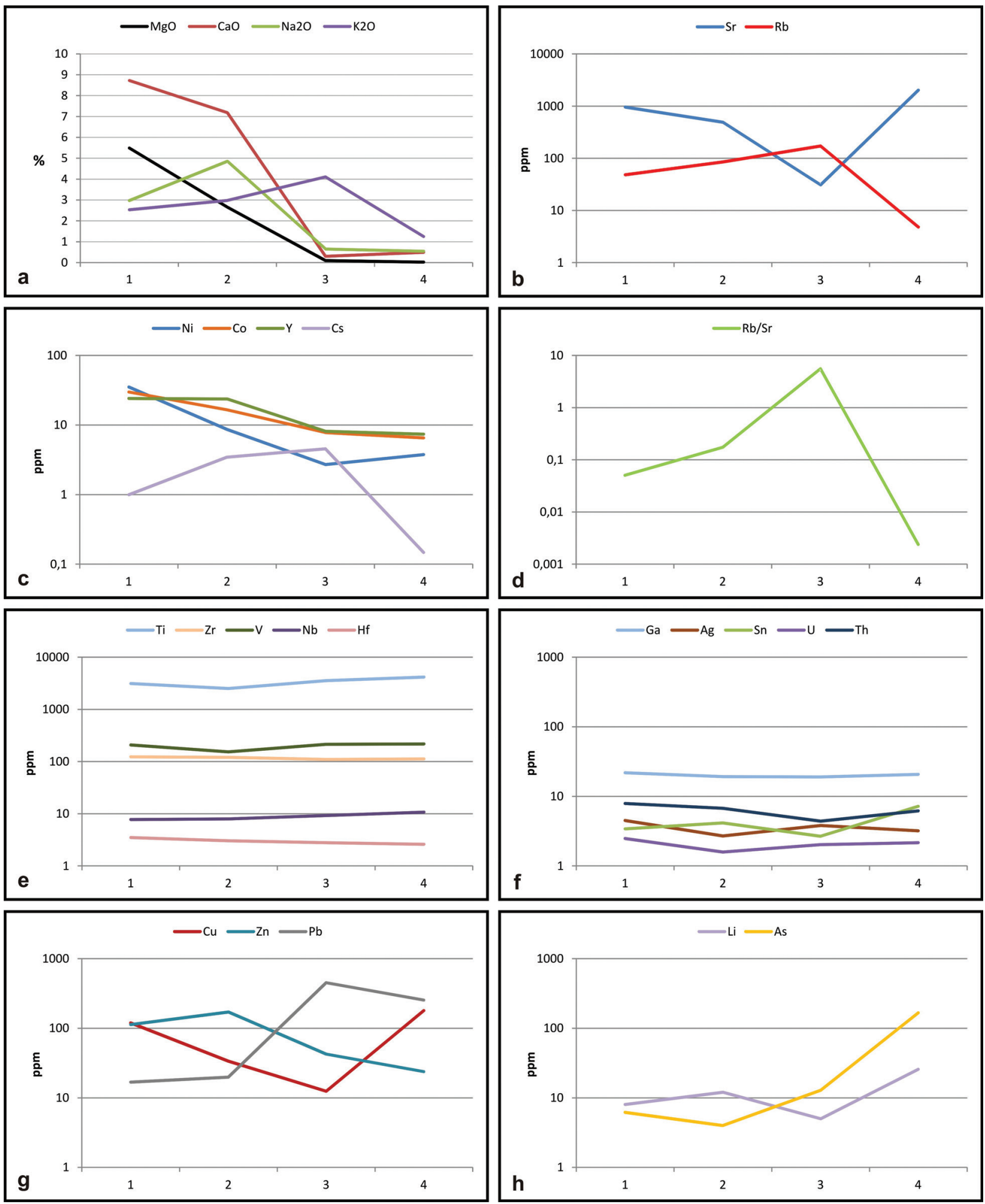

Fig. 5. Distribution of some major and trace elements in the zones of hydrothermal alteration from the Breznik area: 1 - unaltered volcanic rocks; 2 - propylitic; 3 - sericitic; 4 - advanced argillic altered rocks. 
enrichment (Fig. 6b). REE patterns of alunite rocks are characterized with slight depletion of LREE and strong depletion of MREE and HREE, which is stronger compared to pyrophyllite and kaolinite rocks (Fig. 6b).
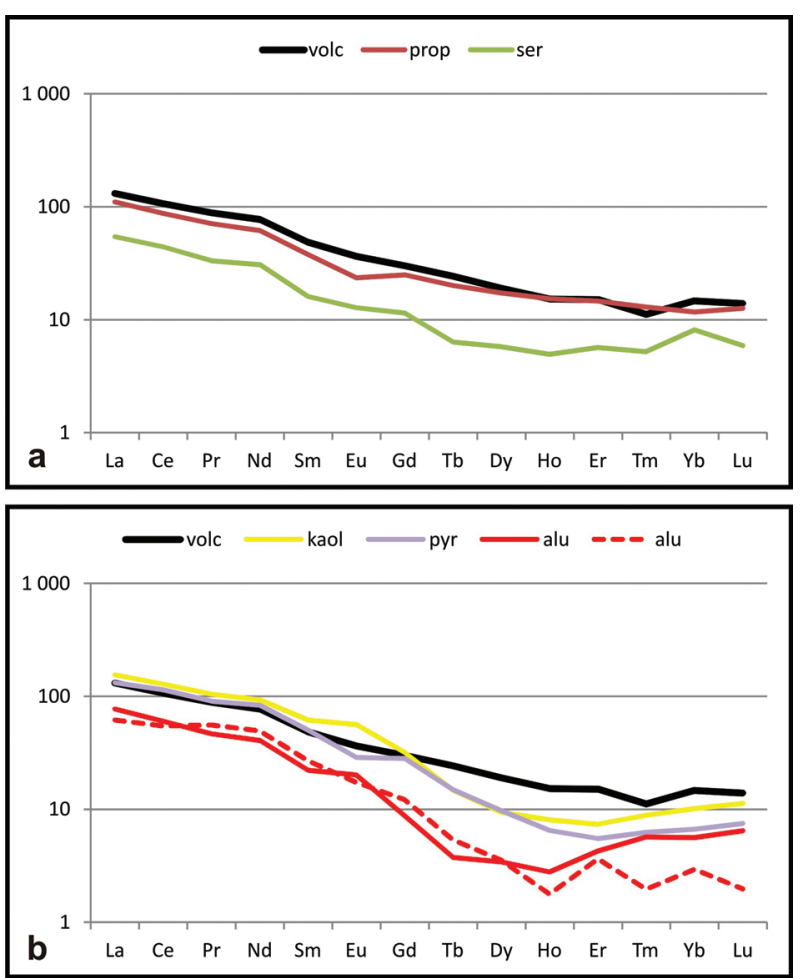

Fig. 6. Chondrite-normalized REE patterns of fresh and altered volcanic rocks from the Breznik area: volc - unaltered volcanic rocks; prop - propylitic; ser - sericitic; advanced argillic altered rocks: kaol-kaolinite, $p y r$ - pyrophillite, alu - alunite.

\section{Geochemistry of alunite group minerals}

Alunite is the main mineral of alunite quartzites in the area of Breznik. Electron microprobe analyses of alunite provide evidence of $\mathrm{K} / \mathrm{Na}$ ratio between 4.6 and 1 (Table 2; Fig. 7). Chemical K-Na zoning in alunite is often seen (Fig. 4a), which is also well documented with Raman spectroscopy (Fig. 8). Permanent admixtures of 2- and 3-valent cations reach to (apfu): $\mathrm{Ca}-$ $0.245, \mathrm{Sr}-0.076, \mathrm{Ba}-0.047, \mathrm{Ce}-0.019, \mathrm{La}-0.004$, $\mathrm{Nd}-0.009$, as well as $\mathrm{F}-0.049$ and $\mathrm{Cl}-0.008$. Phosphorous is usually $<0.132$ apfu but sometimes gets to 0.450 apfu in mixed alunite-APS phases, where admixtures of $\mathrm{Ca}, \mathrm{Sr}, \mathrm{Ba}$ and LREE are highest and $\mathrm{K} / \mathrm{Na}$ ratio decreases.

Aluminium phosphate-sulphate minerals are permanent admixtures in all advanced argillic altered types, usually as microscopic pseudocubic crystals. APS minerals often form the cores of alunite crystals (Fig. $4 b$ ), but the different phases are well identified by Raman spectroscopy (Fig. 8). The composition of APS minerals shows that they are mainly woodhouseite and svanbergite-woodhouseite s.s. (Table 2; Figs 7, 9). Calcium predominates over strontium and $\mathrm{Ca} / \mathrm{Sr}$ ratio varies from 5.21 to 2.06. The highest $\mathrm{Sr}$ content reaches up to 0.246 apfu (5.67\% SrO). Phosphorus/sulphur ratio is usually $<1$ but in some cases is $>1$ (Fig. 9). Permanent admixtures reach to (apfu): $\mathrm{K}-$ $0.246, \mathrm{Na}-0.243, \mathrm{Ba}-0.076, \mathrm{La}-0.016, \mathrm{Ce}-0.025$, $\mathrm{Nd}-0.009, \mathrm{~F}-0.046, \mathrm{Cl}-0.010$.

Jarosite is another mineral from the alunite supergroup that is often seen as supergene product in the region. Its composition is characterized by lack of admixtures, except for small contents of $\mathrm{Ba}$ and $\mathrm{Al}$ (Table 2; Fig. $7 a)$.
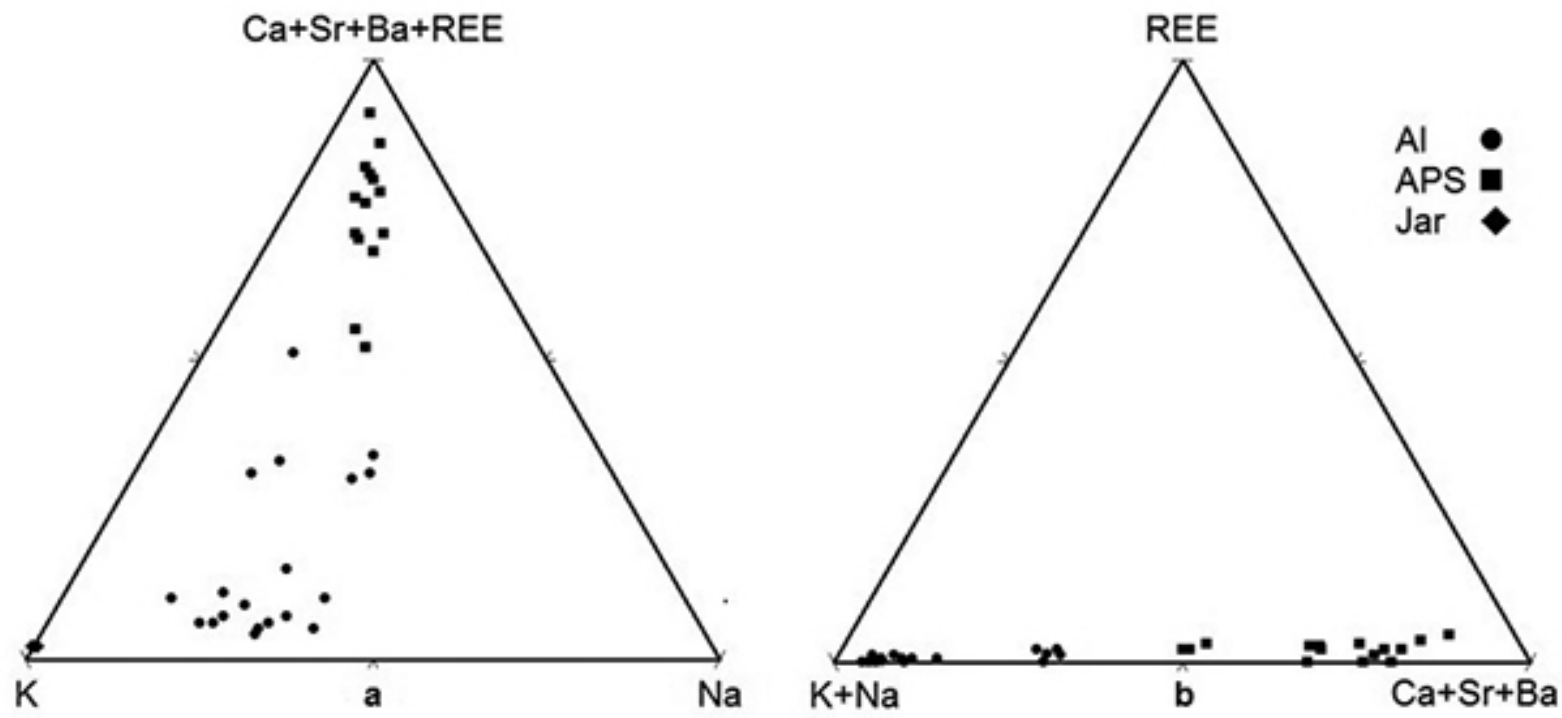

Fig. 7. $D$ position diagrams of alunite and APS minerals: $a) \mathrm{K}-\mathrm{Na}-(\mathrm{Ca}+\mathrm{Sr}+\mathrm{Ba}+\mathrm{REE}) ; b)(\mathrm{K}+\mathrm{Na})-(\mathrm{Ca}+\mathrm{Sr}+\mathrm{Ba})-\mathrm{REE}$. 


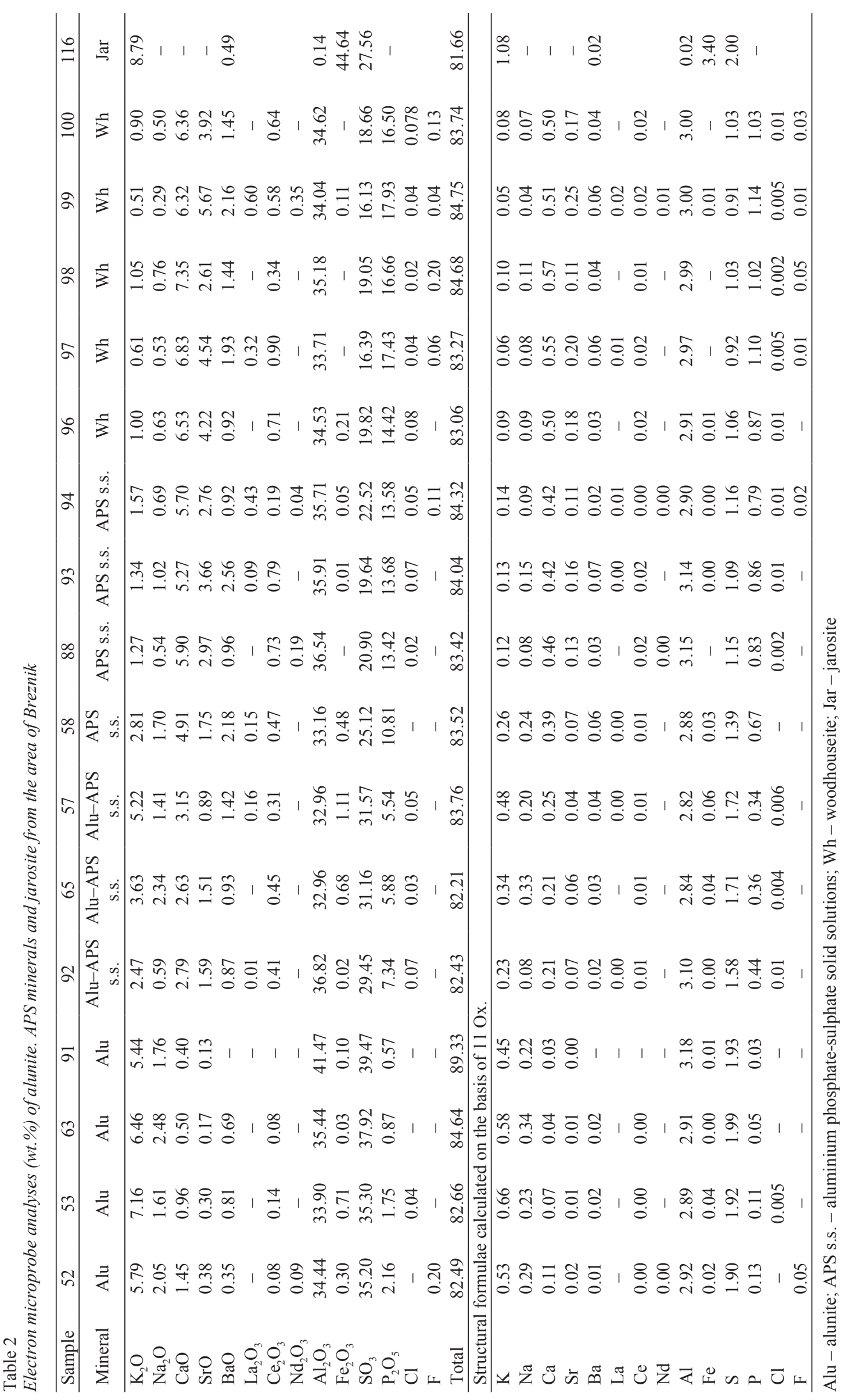




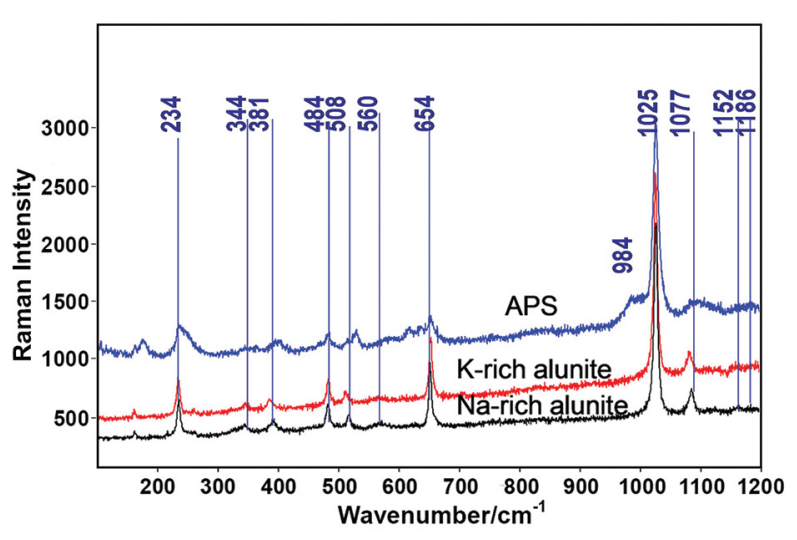

Fig. 8. Raman spectra of pseudocubic grains of APS mineral and of zoned tabular alunite (K-rich and Na-rich).

\section{Chemistry of mineral water}

Mineral water was sampled in the source crosscutting the zone of hydrothermal alteration. The water is orange, due to its high iron concentration. The $\mathrm{pH}$ in the source was measured at 3 . The chemical analysis of water also shows significant concentration of $\mathrm{Ca}, \mathrm{Mg}$, $\mathrm{SO}_{4}{ }^{2-}, \mathrm{Sr}$ and $\mathrm{Rb}$ (Table 3).

The low $\mathrm{pH}$ may be due to the weathering of sulphides, but also to the equilibration of water with advanced argillic alteration. The water chemistry results from the weathering of fresh and hydrothermally altered volcanic rocks. This is the present-day acid-sulphate alteration at low temperatures. The high concentrations of $\mathrm{Fe}, \mathrm{Ca}, \mathrm{Mg}, \mathrm{Sr}$ and $\mathrm{Rb}$ are a result of leaching of propylite and sericite altered rocks and correspond to our data for the zones of hydrothermal alteration in Breznik area and in the Srednogorie Zone (Hikov, 2013). On the other hand, the low concentrations of $\mathrm{PO}_{4}^{3-}, \mathrm{K}$ and $\mathrm{Na}$ could be partly explained by the secondary deposition of APS minerals, alunite and jarosite.

Table 3

Chemical composition of water of Breznik $(\mathrm{mg} / \mathrm{l})$

\begin{tabular}{cccccccccc}
\hline $\mathrm{Ca}$ & $\mathrm{Cl}$ & $\mathrm{Fe}^{*}$ & $\mathrm{~K}$ & $\mathrm{Mg}$ & $\mathrm{Na}$ & $\mathrm{PO}_{4}$ & $\mathrm{SO}_{4}$ & $\mathrm{Rb}$ & $\mathrm{Sr}$ \\
\hline 430 & 8 & 550 & 5 & 239 & 11 & 0.3 & 4218 & 19 & 314 \\
\hline
\end{tabular}

* after Vladeva et al. (2001)

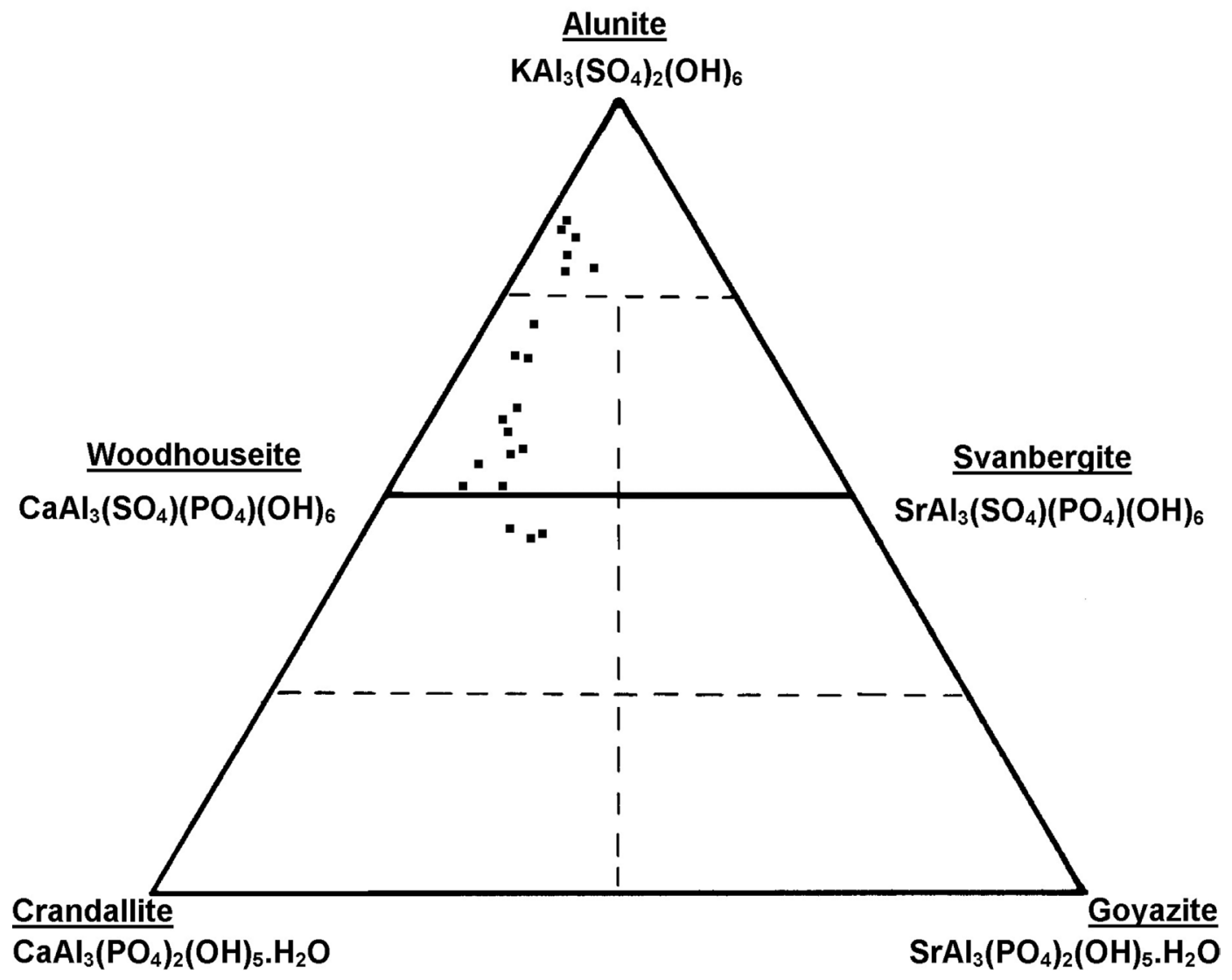

Fig. 9. Composition of alunite and APS minerals from the Breznik area. 


\section{Isotope geochemistry}

The ${ }^{87} \mathrm{Sr} /{ }^{86} \mathrm{Sr}$ ratio of alunite $(0.704861)$ from Breznik area (Table 4) is quite close to the range of ${ }^{87} \mathrm{Sr} /{ }^{86} \mathrm{Sr}$ ratios that characterize the magmatism of the TimokSrednogorie belt [0.7039-0.7061 after 85-90 Ma correction (von Quadt et al., 2003; Kouzmanov et al., 2009)]. This data confirm the magmatic-hydrothermal origin of the alunite of Breznik (Lerouge et al., 2006). The ${ }^{87} \mathrm{Sr} /{ }^{86} \mathrm{Sr}$ ratio of jarosite $(0.704858)$ is close to the ${ }^{87} \mathrm{Sr} /{ }^{86} \mathrm{Sr}$ ratio of alunite, suggesting a common source of strontium for both sulphates. The ${ }^{87} \mathrm{Sr} /{ }^{86} \mathrm{Sr}$ ratio of the water $(0.705459)$ is slightly higher than

Table 4

Strontium, sulfur, oxygen and hydrogen isotopic composition of water, alunite (Alu) and jarosite (Jar) from the area of Breznik

\begin{tabular}{|c|c|c|}
\hline Isotopic signature & water & alunite rocks \\
\hline${ }^{87} \mathrm{Sr}{ }^{86} \mathrm{Sr}$ water & 0.705459 & \\
\hline${ }^{87} \mathrm{Sr} r{ }^{86} \mathrm{Sr} \mathrm{Alu}$ & & 0.704861 \\
\hline${ }^{87} \mathrm{Sr} /{ }^{86} \mathrm{Sr} \mathrm{Jar}$ & & 0.704858 \\
\hline$\delta^{34} \mathrm{~S}_{\mathrm{SO} 4}(\mathrm{CDT})$ & $+3.6 \%$ & \\
\hline$\delta^{34} \mathrm{~S}$ Alu & & $24.1-18.9 \%$ \\
\hline$\delta^{34} \mathrm{~S}$ Jar & & $12.9 \%$ \\
\hline$\delta^{18} \mathrm{O}_{\text {water }}(\mathrm{V}-\mathrm{SMOW})$ & $-10.6 \%$ & \\
\hline$\delta^{18} \mathrm{O}_{\mathrm{SO} 4}$ & $-4.7 \%$ & \\
\hline$\delta^{18} \mathrm{O}$ Alu & & $13.7-14.4 \%$ o \\
\hline$\delta^{18} \mathrm{O}$ Jar & & $11.3 \%$ \\
\hline$\delta \mathrm{D}_{\text {water }}(\mathrm{V}-\mathrm{SMOW})$ & $-71 \%$ & \\
\hline$\delta \mathrm{D}$ Alu & & $-29 \%$ \\
\hline
\end{tabular}

the ${ }^{87} \mathrm{Sr} /{ }^{86} \mathrm{Sr}$ ratio of alunite and jarosite, but remains in the range of the volcanism of the Timok-Srednogorie belt.

The $\delta^{34} \mathrm{~S}$ of sulphates in water at $+3.6 \%$ is slightly higher than the $\delta^{34} \mathrm{~S}$ of sulphides of magmatic origin from the porphyry copper and epithermal deposits from the Panagyurishte District (Kouzmanov et al., 2003; Lerouge et al., 2006) and from the Timok District (Lerouge et al., 2005), as well as from the Milin Kamak epithermal Au-Ag deposit (Sabeva, 2015). The $\delta^{34} S$ values (18.9-24.1\%) of alunite from Breznik area are characteristic of magmatic hydrothermal alunite (Rye et al., 1992), while the $\delta^{18} \mathrm{O}(13.7-14.4 \%$ ) and $\delta \mathrm{D}(-29 \%)$ of alunite show precipitation of magmatic fluids with meteoric waters (Lerouge et al., 2006). These data are very similar to the other alunite manifestations from the Srednogorie Zone (Lerouge et al., 2006). The $\delta^{34} \mathrm{~S}$ of jarosite $(12.9 \%$ o) is intermediate between $\delta^{34} \mathrm{~S}$ of sulphides and $\delta^{34} \mathrm{~S}$ of alunite. That could suggest a preferential mobilization of sulphides during the weathering, but also a slight destabilization of alunite.

\section{DISCUSSION}

The Upper Cretaceous volcanic rocks from the Breznik area were affected by intensive hydrothermal alteration of propylite, sericite and advanced argillic types. Alunite, kaolinite and pyrophyllite advanced argillic rocks have been distinguished. Advanced argillic alteration results from extremely acid $(\mathrm{pH}<2)$, rich in volatiles $\left(\mathrm{CO}_{3}^{2-}, \mathrm{F}^{-}, \mathrm{Cl}^{-}, \mathrm{SO}_{4}^{2-}\right)$ magmatichydrothermal fluids of temperature mostly between $200{ }^{\circ} \mathrm{C}$ and $300{ }^{\circ} \mathrm{C}$ (Meyer and Hemley, 1967; Hemley et al., 1980; Zharikov et al., 1998; Velinov et al., 2007). During hydrothermal alteration, a significant to complete change of mineral and chemical composition of the parent rocks occurred.

The distribution and behaviour of main and trace elements in advanced argillic altered rocks and accompanying hydrothermal alterations in the area of Breznik show several common features with similar hydrothermal alteration zones from the Central and Western Srednogorie and from the Rhodopes (Hikov, 2013). Most characteristic is the behaviour of $\mathrm{Sr}$. The element is depleted from the outer propylite and sericite alteration zones and is accumulated in the inner zones of advanced argillic alteration. The concentration of $\mathrm{Sr}$ is connected with the formation of new strontium minerals. These are aluminium phosphatesulphate (APS) minerals: woodhouseite and svanbergite-woodhouseite s.s. APS minerals form in a broad interval of $\mathrm{pH}(3-8)$ and high activity of $\mathrm{PO}_{4}^{3-}$ (Stoffregen and Alpers, 1987; Ripp et al., 1998; Schwab et al., 2005). The presence of phosphate anion $\mathrm{PO}_{4}{ }^{3-}$ (after apatite dissolution) is crucially important. Apatite is fully preserved in propylitic, partially dissolved in sericitic and completely dissolved in advanced argillic rocks in a low-pH environment (Stoffregen and Alpers, 1987). The liberated $\mathrm{PO}_{4}^{3-}$ and $\mathrm{Ca}^{2+}$ do not move out with the solutions but, together with added $\mathrm{Sr}^{2+}$ and $\mathrm{SO}_{4}{ }^{2-}$ from fluids, form new APS minerals. According to Stoffregen and Alpers (1987), APS minerals can coexist with alunite and kaolinite at $250^{\circ} \mathrm{C}$ and with pyrophyllite between $270{ }^{\circ} \mathrm{C}$ and $350{ }^{\circ} \mathrm{C}$. Part of the strontium is also included in alunite and alunite-APS s.s. (Kashkai, 1970; Hikov, 2004; Hikov et al., 2010; Chang et al., 2011; Georgieva and Velinova, 2012). Similar Sr behaviour has been established in advanced argillic alteration zones from Asarel, Pesovets, Petelovo, Chelopech, Klisura and Spahievo deposits from the Srednogorie Zone and the Rhodopes (Hikov, 2004; Georgieva and Hikov, 2016) and also in other porphyry copper and high-sulphidation epithermal deposits (Schwartz, 1981; Bove and Hon, 1990; Arribas at al., 1995). Permanent presence of APS minerals in the zones of advanced argillic alteration has been documented (Stoffregen and Alpers, 1987; Aoki 
et al., 1993; Hedenquist et al., 1994; Dill, 2001; Georgieva et al., 2002; Kunov et al., 2006; Khashgerel et al., 2008; Hikov et al., 2010; Voudouris and Melfos, 2013). The distribution and behaviour of $\mathrm{Sr}$ in altered rocks in the area of Breznik confirms the hypothesis that "the accumulation of $\mathrm{Sr}$ is a characteristic feature of the process of advanced argillic alteration of volcanic rocks" (Hikov, 2002) and is probably a widespread phenomenon. High concentrations of strontium should be expected everywhere where advanced argillic alteration occurs, because it leads to strontium re-distribution and accumulation. This may be an additional tool in geochemical mapping of advanced argillic alteration zones.

Several elements, such as Rb, Cs, Mn, Ni, Co, Y, HREE, etc., are very mobile and are depleted in advanced argillic zones. Rubidium, in contrast to the other elements, is accumulated in sericite rocks, being fully depleted in advanced argillic altered rocks. The behaviour of $\mathrm{Rb}$ is opposite to that of $\mathrm{Sr}$, which leads to high $\mathrm{Rb} / \mathrm{Sr}$ ratio in sericite rocks and extremely low $\mathrm{Rb} / \mathrm{Sr}$ ratio in advanced argillic altered rocks, as in other advanced argillic altered zones from the Srednogorie Zone and the Rhodopes (Hikov, 2004). Thus, the $\mathrm{Rb} / \mathrm{Sr}$ ratio should be recommended for geochemical prospecting. Anomalously low values of $\mathrm{Rb} / \mathrm{Sr}$ ratio are typical for advanced argillic zones and suggest high-sulphidation epithermal system, while high values are characteristic for sericite rocks and could be perspective for prospecting of porphyry copper or low-sulphidation epithermal mineralization (Armbrust et al., 1977; Arribas et al., 1995; Hikov, 2004).

Low mobility of LREE and pronounced mobility of MREE and HREE have been registered in advanced argillic alteration zones from Breznik area, which is characteristic for advanced argillic zones from the Central Srednogorie Unit (Hikov, 2014; Georgieva and Hikov, 2016). The mobility of MREE and HREE is connected with the high activity of $\mathrm{F}^{-}$, low $\mathrm{pH}$ of the fluids, high water/rock ratio and their ability to form stable complexes in these conditions (Lottermoser, 1992; Fulignati et al., 1999). LREE are relatively immobile (with slight enrichment in kaolinite and pyrophyllite rocks), due to their entrance in the lattice of appropriate minerals like alunite, APS minerals and clay minerals (Aja, 1998; Fulignati et al., 1999; Kikawada et al., 2004; Hikov et al., 2010). APS minerals are usually svanbergite-woodhouseite s.s., but locally florencite may form (Hikov et al., 2010; Georgieva and Velinova, 2014). The slight depletion of LREE in alunite rocks from Breznik area is probably due to the prolonged influence of extremely acid fluids, which have not allowed all LREE to include in the newly forming minerals.

Comparatively inert behaviour during hydrothermal alteration have $\mathrm{Zr}, \mathrm{Ti}, \mathrm{V}, \mathrm{Ga}, \mathrm{Hf}, \mathrm{Nb}, \mathrm{Th}, \mathrm{U}$ and, to a lesser extent, $\mathrm{Cr}, \mathrm{Ta}, \mathrm{Sn}$ and $\mathrm{Ba}$. This is due to the relative stability of their minerals (titanite, zircon, apatite) in the outer propylite and sericite alteration zones. During advanced argillic alteration, these minerals are dissolved, the majority of MREE and HREE are liberated and migrate, having high mobility under these conditions. The elements $\mathrm{Ti}, \mathrm{V}$ and $\mathrm{Zr}$ do not migrate, and form new mineral phases: rutile and microscopic zirconium phases [zircon and/or baddeleyite (Hikov, 2013)], which concentrate Ti, V, Sn, Nb, Ta, $\mathrm{Zr}$, Hf, partially U, Th, etc. LREE and other inert elements take part in alunite and APS minerals. Alunite and APS minerals are characteristic for advanced argillic alteration and high-sulphidation epithermal deposits (Sillitoe and Hedenquist, 2003) but also control the geochemistry of a number of chemical elements, which concentrate or are immobile in advanced argillic zones (Hikov, 2013). These are $\mathrm{K}, \mathrm{Na}, \mathrm{Ca}, \mathrm{Sr}$, $\mathrm{Ba}, \mathrm{P}, \mathrm{La}, \mathrm{Ce}, \mathrm{Nd}$ and, partly, $\mathrm{Pb}$ (Chang et al., 2011; Hikov, 2013), in some cases Ga (Boriskin, 1967; Rytuba et al., 2003), Sc and V (Kashkai, 1970), U and Th (Khashgerel et al., 2008).

Arsenium concentrates several times in advanced argillic altered rocks, which, together with the higher contents of $\mathrm{Sb}, \mathrm{Te}$ and $\mathrm{Bi}$, is indication of high-sulphidation epithermal environment (Hedenquist et al., 2000). Increased concentration of $\mathrm{Li}$ is documented only in kaolinite-containing advanced argillic rocks, where Li is possibly included in the crystal lattice of kaolinite (Starkey, 1982). The same behaviour of Li has been registered in other hydrothermal alteration zones from the Srednogorie Zone and the Rhodopes (Hikov, 2013).

The isotope data show magmatic-hydrothermal origin of alunite, as well as the volcanic host rocks as a source for Sr (von Quadt et al., 2003; Lerouge et al., 2006; Kouzmanov et al., 2009). This confirms the assumption of $\mathrm{Sr}$ redistribution during advanced argillic alteration and related alteration types without support from any outer source (Hikov, 2004, 2013). It is not excluded that some APS minerals have supergene origin, but most of them are formed during advanced argillic alteration close to, together or just later than the alunite. Despite of the variable compositions of alunite and APS minerals, their formation can be associated with a single fluid with the gradual depletion of its individual components (Figs 7a, 9). APS minerals occur in the alunite zone, but also in kaolinite and in pyrophyllite advanced argillic rocks. Their presence in pyrophyllite zone strongly suggests that APS minerals are formed at temperatures about or over $300{ }^{\circ} \mathrm{C}$ (Hemley et al., 1980; Stoffregen and Alpers, 1987).

Nowadays, as a result of pyrite oxidation during weathering, acid-sulphate environment is created, which leads to leaching of $\mathrm{Fe}, \mathrm{Ca}, \mathrm{Mg}, \mathrm{Sr}$ and $\mathrm{Rb}$ from volcanic rocks and zones of propylitization and sericitization. New minerals as jarosite and possibly APS minerals are formed, which are stable in these conditions. There are not registered admixtures of $\mathrm{Sr}$ in jarosite, so the accumulation of $\mathrm{Sr}$ in advanced argillic rocks does not realize in supergene conditions 
and dissolved $\mathrm{Sr}$ migrates with surficial waters. The formation of jarosite during weathering of pyrite-rich rocks requires more extreme acidity and more oxidizing conditions than alunite (Stoffregen et al., 2000). It is supposed that the formation of alunite and APS minerals, as well as the participation of 2- and 3-valent cations in the alunite group minerals, in these conditions is very limited.

The development of advanced argillic altered rocks as a part of a hydrothermally altered zone near Breznik and their mineral and chemical composition (concentration of $\mathrm{Sr}$ and $\mathrm{As}$, depletion of $\mathrm{Rb}$, typical distribution of REE, magmatic-hydrothermal alunite, permanent presence of APS minerals, etc.) define a high-sulphidation epithermal environment (White and Hedenquist, 1990; Hedenquist et al., 1996). Milin Kamak ore deposit is situated at the periphery of advanced argillic altered zone and is described as $\mathrm{Au}-\mathrm{Ag}$ intermediate sulphidation epithermal deposit with local development of high-sulphidation epithermal type (Sabeva, 2015). According to Crummy et al. (2001), the erosional level is around $250-300 \mathrm{~m}$, which does not allow rich high-sulphidation ore concentrations to be found. On the other hand, the presence of hightemperature pyrophyllite advanced argillic rocks and actinolite containing propylite rocks, as well as the data for temperatures of $\sim 400^{\circ} \mathrm{C}$ from fluid inclusions (Moritz et al., 2007), suggest the presence of magmatic source under the advanced argillic zone. For that reason, the idea for development of porphyry system at depth (Moritz et al., 2007) should not be rejected and needs to be assessed.
Increased contents of elements such as $\mathrm{As}, \mathrm{Sb}$, $\mathrm{Te}, \mathrm{Bi}$ and $\mathrm{Li}$ are characteristic for advanced argillic zones in the upper epithermal parts of porphyry copper systems (Halley et al., 2015). A more detailed geochemical study of the indicator elements in the area of Breznik can outline the centre of the magmatichydrothermal system, as well as point to potentially porphyry ore mineralization.

\section{CONCLUSIONS}

The present geochemical studies of the hydrothermally altered rocks in the area of Breznik confirm that they belong to the epithermal part of a magmatic-hydrothermal system. Discovering of epithermal Au-Ag mineralizations, which are in spatial and genetic connection with hydrothermally altered rocks in the area of Breznik and both are part of the same magmatic-hydrothermal system, hold out new prospective for additional exploration works in the region, especially for potentially porphyry ore mineralization. Metalogenic re-evaluation should be made of the whole Western Srednogorie Unit, which until recently was not considered prospective for new ore deposits (Vassileff and Stanisheva-Vassileva, 1989), in spite of its location between the rich Panagyurishte and Timok ore regions.

\section{Acknowledgements}

The authors wish to thank Dr Zlatka Cherneva, the official journal reviewer, for helpful comments and suggestions during the review process.

\section{REFERENCES}

Aja, S.U. 1998. The sorption of the rare earth element, Nd, onto kaolinite at $25{ }^{\circ} \mathrm{C}$. Clays and Clay Minerals 46, 103-109.

Aoki, M., Comsti, E., Lazo, F., Matsuhisa, Y. 1993. Advanced argillic alteration and geochemistry of alunite in an evolving hydrothermal system at Baguio, Northern Luzon, Philippines. Resource Geology 43, 155-164.

Armbrust, G., Oyarzun, J., Arias, J. 1977. Rubidium as a guide to ore in Chilean porphyry copper deposits. Economic Geology 72, 1086-1100.

Arribas, A., Cunningham, C., Rytuba, J., Rye, R., Kelly, W., Podwysocki, M., McKee, E., Tosdal, R. 1995. Geology, geochronology, fluid inclusion, and isotope geochemistry of the Rodalquilar gold alunite deposit, Spain. Economic Geology 90, 795-822.

Bajraktarov, I. 1989. Upper Cretaceous metallogeny of the Western Srednogorie and the Plana Mountain. Abstract of $\mathrm{PhD}$ thesis, Sofia, $39 \mathrm{pp}$. (in Bulgarian).

Bajraktarov, I. 1994. Détérmination de unités métallogéniques dans la région de Srednogorie occidental et de montagne de Plana. Ore-Forming Processes and Mineral Deposits 35, 3-12 (in Bulgarian, with French abstract).
Bajraktarov, I., Mutafchiev, A. 1981. Detected paleovolcanic edifices in Western Srednogorie. Rudodobiv Journal 4, p. 24 (in Bulgarian).

Belev, S. 1967. Recherches sur la petrographie et la tectonique de la depression de Breznik. Review of the Bulgarian Geological Society 28 (2), 139-152 (in Bulgarian, with French abstract).

Boccaletti, M., Manetti, P., Peccerillo, A. 1974. The Balkanides as an instance of back-arc thrust belt. Possible relation with the Hellenides. Geological Society of America Bulletin 85, 1077-1084.

Bončev, E. 1971. Problems of Bulgarian geotectonics. Tehnika, Sofia, 204 pp. (in Bulgarian).

Boriskin, V. 1967. Distribution of gallium in Aksakate alunite quartzites. Proccedings of the Uzbek Academy of Sciences 3, 35-37 (in Russian).

Bove, D., Hon, K. 1990. Compositional changes induced by hydrothermal alteration at the Red Mountain alunite deposit, Lake City, Colorado. US Geological Survey Bulletin 1936, $21 \mathrm{pp}$.

Carter, G.S. 2011. Technical report on the gold and silver resources at Breznik property, Pernik and Breznik munici- 
palities, Pernik district, Bulgaria. Broad Oak Associates, Toronto, Canada, 79 pp.

Chang, Z., Hedenquist, J., White, N., Cooke, D., Roach, M., Deyell, C., Garcia, J., Bruce Gemmell, J., McKnight, S., Cuison, A. 2011. Exploration tools for linked porphyry and epithermal deposits: Example from the Mankayan intrusion-centered $\mathrm{Cu}-\mathrm{Au}$ district, Luzon, Philippines. Economic Geology 106, 1365-1398.

Crummy, J., Mutafchiev, I., Velinov, I., Petrunov, R. 2001. The Breznik epithermal Au occcurence, Western Srednogorie - Bulgaria: an "atypical" (?) low-sulphidation hydrothermal system. In: Piestrzynski et al. (Eds), Proceedings of the Joint Sixth Biennial SGA-SEG Meeting, Krakow, Poland, 723-726.

Dabovski, Ch., Kamenov, B., Vasilev, E., Bajraktarov, I. 2009. Upper Cretaceous geology. In: Zagorchev, I., Dabovski, Ch., Nikolov, T. (Eds), Geology of Bulgaria. Volume II. Mesozoic Geology. "Prof. Marin Drinov" Academic Publishing House, Sofia, 423-553 (in Bulgarian, with English summary).

Dill, H. 2001. The geology of aluminium phosphates and sulphates of the alunite group minerals: a review. Earth Science Review 53, 35-93.

Dimitrov, R., Belev, S. 1970. Evolution of volcanity in the eruptive zone of the Lyulin-Zavalska Mountain. Review of the Bulgarian Geological Society 31 (3), 315-322 (in Bulgarian, with English abstract).

Dimitrova, E., Ganeva, N., Jolkicev, N., Milanova, J., Nachev, I. 1981. Upper Cretaceous stratigraphy in W Srednogorie. Geologica Balcanica 11 (1), 51-66.

Fulignati, P., Gioncada, A., Sbrana, A. 1999. Rare-earth element (REE) behaviour in the alteration facies of the active magmatic-hydrothermal system of Vulcano (Aeolian Islands, Italy). Journal of Volcanology and Geotermal Research $88,325-342$.

Georgieva, S., Hikov, A. 2016. Geochemistry of hydrothermally altered rocks from the Chelopech high-sulphidation $\mathrm{Cu}-\mathrm{Au}$ deposit, Bulgaria. Comptes rendus de l'Académie bulgare des Sciences 69, 761-768.

Georgieva, S., Velinova, N. 2012. Alunite from the advanced argillic alterations in the Chelopech high-sulphidation epithermal $\mathrm{Cu}-\mathrm{Au}$ deposit, Bulgaria: Chemistry, morphology and genetic significance. Geochemistry, Mineralogy and Petrology 49, 17-31.

Georgieva, S., Velinova, N. 2014. Florencite-(Ce, La, Nd) and crandallite from the advanced argillic alterations in the Chelopech high-sulphidation epithermal $\mathrm{Cu}-\mathrm{Au}$ deposit, Bulgaria. Comptes rendus de l'Académie bulgare des Sciences 67, 1669-1678.

Georgieva, S., Velinova, N., Petrunov, R., Moritz, R., Chambefort, I. 2002. Aluminium phosphate-sulphate minerals in the Chelopech $\mathrm{Cu}-\mathrm{Au}$ deposit: Spatial development, chemistry and genetic significance. Geochemistry, Mineralogy and Petrology 39, 39-51.

Gočev, P.M., Kostadinov, V., Matova, M., Velinov, I. 1970. The structure of a part of the Southern strip of the Western Srednogorie. Review of the Bulgarian Geological Society 31 (3), 289-301 (in Bulgarian, with English abstract).

Halley, S., Dilles, J., Tosdal, R. 2015. Footprints: Hydrothermal alteration and geochemical dispersion around porphyry copper deposits. SEG newsletter 100, 1-17.

Hedenquist, J., Arribas, A., Gonzalez-Urien, E. 2000. Exploration for epithermal deposits. Reviews in Economic Geology 13, 245-277.

Hedenquist, J., Izawa, E., Arribas, A., White, N. 1996. Epithermal gold deposits: Styles, characteristics, and exploration. Resource Geology, Special Publication 1, 20 pp.
Hedenquist, J., Matsuhisa, Y., Izawa, E., White, N., Giggenbach, W., Aoki, M. 1994. Geology, geochemistry, and origin of high sulphidation $\mathrm{Cu}-\mathrm{Au}$ mineralization in the Nansatsu District, Japan. Economic Geology 89, 1-30.

Hemley, J., Montoya, J., Marinenko, J., Luce, R. 1980. Equilibria in the system $\mathrm{Al}_{2} \mathrm{O}_{3}-\mathrm{SiO}_{2}-\mathrm{H}_{2} \mathrm{O}$ and some general implications for alteration mineralization processes. Economic Geology 75, 210-228.

Hikov, A. 2002. Geochemistry of hydrothermally altered rocks in Klisoura occurrence, Sofia district. Geologica Balcanica 32 (2-4), 89-92.

Hikov, A. 2004. Geochemistry of strontium in advanced argillic alteration systems - possible guide to exploration. Bulgarian Geological Society, Annual Scientific Conference "Geology 2004", Abstracts, 29-31.

Hikov, A. 2013. Geochemistry of advanced argillic alteration zones of deposits from Srednogorie and Rhodopes regions. Abstract of $\mathrm{PhD}$ thesis, Geological Institute, Bulgarian Academy of Sciences, Sofia, 62 pp. (in Bulgarian).

Hikov, A. 2014. REE mobility during advanced argillic alteration in some epithermal and porphyry copper systems from Central Srednogorie, Bulgaria. Proceedings of the $X X^{\text {th }}$ CBGA Congress, Tirana, Albania, 154-157.

Hikov, A., C. Lerouge, N. Velinova. 2010. Geochemistry of alunite group minerals in advanced argillic altered rocks from the Asarel porphyry copper deposit, Central Srednogorie. Review of the Bulgarian Geological Society 71 (1-3), 133-148.

Kanazirski, M. 2011. Hydrothermal wallrock alterations. Physicochemical accents. "Prof. Marin Drinov" Academic Publishing House, Sofia, 254 pp. (in Bulgarian, with English abstract).

Kashkai, M.A. 1970. Alunites, their genesis and utilization. Nedra, Moskow, 1, 400 pp.; 2, 317 pp. (in Russian).

Khashgerel, B.-E., Kavalieris, I., Hayashi, K. 2008. Mineralogy, textures, and whole-rock geochemistry of advanced argillic alteration: Hugo Dummett porphyry $\mathrm{Cu}-\mathrm{Au}$ deposit, Oyu Tolgoi mineral district, Mongolia. Mineralium Deposita 43, 913-932.

Kikawada, Y., Ugura, M., Oi, T., Honda, T. 2004. Mobility of lanthanides accompanying the formation of alunite group minerals. Journal of Radioanalytical Nuclear Chemistry 261, 651-659.

Kouzmanov, K., Moritz, R., von Quadt, A., Chiaradia, M., Peytcheva, I., Fontignie, D., Ramboz, C., Bogdanov, K. 2009. Late Cretaceous porphyry $\mathrm{Cu}$ and epithermal $\mathrm{Cu}-\mathrm{Au}$ association in the Southern Panagyurishte District, Bulgaria: the paired Vlaykov Vruh and Elshitsa deposits. Mineralium Deposita 44, 611-646.

Kouzmanov, K., Ramboz, C., Lerouge, C., Deloule, E., Beaufort, D., Bogdanov, K. 2003. Stable isotopic constrains on the origin of epithermal $\mathrm{Cu}-\mathrm{Au}$ and related porphyry copper mineralisation in the southern Panagyurishte district, Srednogorie zone, Bulgaria. In: Elioupoulos, D. et al. (Eds), Mineral exploration and sustainable development. Proceedings of the $7^{\text {th }}$ Biennial SGA Meeting, Athens 2003. Millpress, Rotterdam, Netherlands, 1181-1184.

Kunov, A., Hikov, A., Velinova, N. 2006. Aluminium phosphate-sulphate minerals from the advanced argillic alteration systems in Bulgaria. Proceedings of the $18^{\text {th }}$ Congress of CBGA, Belgrade, Serbia, 306-309.

Lerouge, C., Bailly, L., Béchu, E., Fléhoc, C., Genna, A., Lescuyer, J.L., Stein, G., Gillot, P.Y., Kozelj, D. 2005. Age and origin of advanced argillic alteration at the Bor $\mathrm{Cu}-\mathrm{Au}$ deposit, Serbia. In: Mao, J., Berlein, F. (Eds), Mineral deposit research: Meeting the global challenge. Proceedings of the $8^{\text {th }}$ Biennial SGA Meeting, Beijing, China. Springer-Verlag, Berlin, Heidelberg, 541-544. 
Lerouge, C., Fléhoc, C., Kunov, A., Hikov, A., Georgieva, S., Lescuyer, J.L., Petrunov, R., Velinova, N. 2006. Constraints of stable isotopes on the origin of alunite from advanced-argillic alteration systems in Bulgaria. Journal of Geochemical Exploration 90, 166-182.

Lerouge, C., Hikov, A., Beny, C., Fléhoc, C., Guerrot, C., Kunov, A., Yanev, Y. 2007. Constraints of stable isotopes, Raman spectrometry on the formation of the advanced argillic alteration of the Breznik epithermal Au occurrence in Bulgaria - impact of weathering. Proceedings of the $9^{\text {th }}$ Biennial SGA Meeting, Dublin, 885-888.

Lottermoser, B.G. 1992. Rare earth elements and hydrothermal ore formation processes. Ore Geology Review 7, 25-41.

Marinov, T., Bayraktarov, I. 1980. Alkaline basalts in the Western Srednogorie. Comptes rendus de l'Académie bulgare des Sciences 33 (4), 529-532.

Marinova, R., Grozdev, V., Ivanova, D., Sinnyovsky, D., Petrov, I., Milovanov, P., Popov, A. 2010. Explanatory note for the geological map of Bulgaria in scale 1:50 000, Breznik map sheet. Ministry of Environment and Water, Bulgarian National Geological Survey, Sofia, 63 pp. (in Bulgarian).

Meyer, C., Hemley, J. 1967. Wall rock alteration. In: Barnes, H.L. (Ed.), Geochemistry of hydrothermal ore deposits. New York, Holt, Rinehart and Winston, 166-235.

Moritz, R., Petrunov, R., Stoykov, S., Todorov, J., Strashimirov, S. 2007. The Breznik gold prospect, late Cretaceous Srednegorie belt, Bulgaria: evidence for an epithermal system telescoping a porphyry environment. Proceedings of the $9^{\text {th }}$ Biennial SGA Meeting, Dublin, 193-196.

Nachev, I., Ganeva, N., Milanova, J. 1981. Upper Cretaceous Sedimentology in the Western Srednogorie Region. Paleontology, Stratigraphy and Lithology 14, 29-64 (in Bulgarian, with English abstract).

Panayotov, A., Zvetkov, K., Sapoundjiev, K., Stoyanov, Y. 1982. Complex investigations for prospecting of minerals in Western "Sredna Goga" in accordance with "Bardoto", Breznishko mineral field. Annual of Commitee of Geology, Ministry of Metallurgy and Mineral Resources 22, 103-111 (in Bulgarian, with English and Russian abstracts).

Popov, P., Berza, T., Grubić, A., Ioane, D. 2002. Late Cretaceous Apuseni-Banat-Timok-Srednogorie (ABTS) magmatic and metallogenic belt in the Carpathian-Balkan orogen. Geologica Balcanica 32 (2-4), 145-163.

Ripp, G., Kanakin, S., Shcherbakova, M. 1998. Phosphate mineralization in metamorphosed high-alumina rocks of Ichetuyskoe ore occurrence (south-west Transbaikali). Proceedings of the Russian Mineralogical Society 127 (6), 98-108 (in Russian, with English abstract).

Rye, R., Bethke, P., Wasserman, M. 1992. The stable isotope geochemistry of acid sulfate alteration. Economic Geology $87,225-262$.

Rytuba, J., John, D., Foster, A., Ludington, S., Kotlyar, B. 2003. Hydrothermal enrichment of gallium in zones of advanced argillic alteration - examples from the Paradise Peak and McDermitt ore deposits, Nevada. US Geological Survey Bulletin 2209-C, 20 pp.

Sabeva, R. 2015. Milin Kamak gold deposit, Western Srednogorie: hydrothermal alteration, mineral composition, genesis. $\mathrm{PhD}$ thesis, Sofia University, 180 pp. (in Bulgarian).

Schwab, R., Pimpl, T., Schukow, H., Stolle, A., Breitinger, D. 2005. Compounds of the crandallite-type: Synthesis, properties and thermodynamic data of $\mathrm{Ca}-\mathrm{Sr}-\mathrm{Ba}-\mathrm{Pb}-($ arseno)woodhouseites. Neues Jahrbuch für Mineralogie Abhandlungen 181 (3), 207-218.

Schwartz, M. 1981. The geochemistry of the leached capping of the La Granja porphyry copper deposit, Peru. Journal of Geochemical Exploration 15, 93-113.
Sillitoe, R., Hedenquist, J. 2003. Linkages between volcanotectonic settings, orefluid compositions, and epithermal precious metal deposits. Society of Economic Geologists, Special Publication 10, 315-343.

Starkey, H. 1982. The role of clays in fixing lithium. Geological Survey Bulletin 1278-F, 11 pp.

Stoffregen, R., Alpers, Ch. 1987. Svanbergite and woodhouseite in hydrothermal ore deposits: Implications for apatite destruction during advanced argillic alteration. Canadian Mineralogist 25, 201-212.

Stoffregen, R., Alpers, Ch., Jambor, J. 2000. Alunite-Jarosite crystallography, thermodynamics, and geochronology. Reviews in Mineralogy and Geochemistry 40, 453-479.

Stoykov, S., Strashimirov, S., Moritz, R., Dimitrov, D., Todorov, J. 2007. Mineral composition of the Breznik-Bardoto Au epithermal ore occurrence (preliminary data). Annual of the University of Mining and Geology "St Ivan Rilski" 50 (1), 117-122.

Vassileff, L., Stanisheva-Vassileva, G. 1981. Metallogeny of the Eurasian Copper Belt. Sector Bulgaria. Geologica Balcanica 11 (2), 73-87.

Vassileff, L., Stanisheva-Vassileva, G. 1989. Why the metallogeny of the Western Srednogorie is so frail? Geologica Balcanica 19 (6), p. 40 (in Russian).

Velinov, I. 1967. Propylites and alunite quartzites in the area of Breznik. Bulletin of the Geological Institute, Geochemistry, Mineralogy and Petrography 16, 205-220 (in Bulgarian, with English abstract).

Velinov, I., Kunov, A., Velinova, N. 2007. The metasomatic secondary quartzite formation in Bulgaria. "Prof. Marin Drinov" Academic Publishing House, Sofia, 198 pp.

Vladeva, L., Krasteva, D., Yordanov, J., Kostadinov, D. 2001. Reference book for Bulgarian mineral waters. Nauka i Tehnika, Sofia, 225 pp. (in Bulgarian).

von Quadt, A., Peytcheva, I., Cvetković, V. 2003. Geochronology, geochemistry and isotope tracing of the Cretaceous magmatism of East-Serbia and Panagyurishte district (Bulgaria) as part of the Apuseni-Timok-Srednogorie metallogenic belt in Eastern Europe. In: Elioupoulos, D. et al. (Eds), Mineral exploration and sustainable development, Proceedings of the $7^{\text {th }}$ Biennial SGA Meeting, Athens. Millpress, Rotterdam, Netherlands, 407-410.

Voudoris, P., Melfos, V.2013. Aluminium-phosphate-sulfate (APS) minerals in the sericite-advanced argillic alteration zone of the Melitena porphyry-epithrmal Mo-Cu $\pm \mathrm{Au} \pm$ Re prospect, Western Thrace, Greece. Neues Jahrbuch für Mineralogie Abhandlungen 190 (1), 11-27.

Vrablyanski, B. 1971. Sofia synclinorium. In: Yovchev, Y. (Ed.), Tectonic structure of Bulgaria. Technika, Sofia, 349-350 (in Bulgarian, with English abstract).

White, N., Hedenquist, J. 1990. Epithermal environments and styles of mineralization: Variations and their causes, and guidelines for exploration. Journal of Geochemical Exploration 36, 455-474.

Zagorchev, I., Kostadinov, V., Tchounev, D., Dimitrova, R., Sapunov, I., Tchoumachenko, P., Yanev, S. 1995. Explanatory note for the geological map of Bulgaria in scale 1:100 000 . Vlasotintse and Breznik map sheets. Committee of Geology and Mineral Resources, "Geology and Geophysics" Corporation, Sofia, 107 pp. (in Bulgarian, with English abstract).

Zharikov, V., Omel'yanenko, B. 1978. Clasification of metasomatites. In: Metasomatism and ore-forming processes. Nauka, Moscow, 9-28 (in Russian).

Zharikov, V., Rusinov, V., Marakushev, A., Zaraiskii, G., Omel'yanenko, B., Pertsev, N., Rass, I., Andreeva, O., Abramov, S., Podlesskii, K. 1998. Metasomatism and metasomatic rocks. Scientific World, Moscow, 489 pp. (in Russian). 